\title{
還元有機泥が堆積した海域の底質改善に 用いられる石炭灰造粒物の生物親和性評価
}

\author{
中本 健二 1 -樋野 和俊 2 及川 隆仁 3 -日比野 忠史 4 \\ 1 正会員 広島大学大学院 工学研究科（下739-8527 広島県東広島市鏡山 1-4-1） \\ E-mail:d134328@ hiroshima-u.ac.jp \\ 2 正会員 中国電力株式会社 電源事業本部（广730-8701 広島市中区小町4-33） \\ E-mail:366369@pnet.energia.co.jp \\ 3 正会員 中国電力株式会社 エネルギア総合研究所（テ739-0046 東広島市鏡山 3-9-1） \\ E-mail:352555@pnet.energia.co.jp \\ 4 正会員広島大学大学院准教授 工学研究院（干739-8527 広島県東広島市鏡山 1-4-1） \\ E-mail:hibinot@hiroshima-u.ac.jp
}

\begin{abstract}
広島湾沿岸域では，還元有機泥が底質に堆積し生物生息環境の悪化を招いている干潟，浅場がある。こ の底質改善に石炭灰（FA）を造粒・固化した海砂代替材（石炭灰造粒物）が覆砂材として活用され底質改 善効果が確認されているが，その材料特性による生物親和性（微生物および珪藻類の選好的付着性状，二 枚貝等底生生物の選好性状）については十分に明らかにされていない，本研究は，石炭灰造粒物を還元有 機泥が堆積した海域底質の覆砂材として活用する場合の生物親和性について, 室内および現場実験により 明らかにすることを目的とした，石炭灰造粒物と対照基質（在来底質，自然石，砂およびセメント固化体） の物理化学特性, 溶存態イオン溶出特性, 微生物の付着, 珪藻類の付着および二枚貝の行動選好性に関す る実験，調査により生物親和性を評価した。
\end{abstract}

Key Words : tidal flat, coastal sediment, biological affinity, granulated coal ash, covering material

\section{1. はじめに}

広島湾沿岸域では，人口の増加によりしばしば未処理 下水が放流され河岸のへドロ（還元有機泥）化が確認さ れている，広島湾は閉鎖性海域であり，還元有機泥が底 質に堆積し生物生息環境の悪化を招いている湾域, 浅場, および干潟がある．また，広島湾は波が穏やかであるこ とからカキの垂下式養殖法が広範囲に行われている。こ れらのカキ筏下の底層環境は, カキの成長に伴う排泄物 が長年堆積するとともに，力キの収穫作業や台風による 波浪の影響等外的要因によりコレクター（ホタテガイの 貝殼にマガキの稚貝を付着させたもの）から脱落したカ キが死滅し軟体部が腐敗して，貧酸素化が進行するとの 報告もある ${ }^{1)}$.

これら海域の底質改善に石炭灰（FA）を造粒・固化し た海砂代替材（石炭灰造粒物）が覆砂材（写真-1）とし て活用され底質改善効果が確認されている. しかし，そ の材料特性による生物親和性（微生物およひ珪藻類の選 好的付着性状，二枚貝等底生生物の選好性状）について は十分に明らかにされていない．本研究の目的は，石炭 灰造粒物を覆砂材および干潟再生材として活用する場合
の生物親和性について，実験（室内，現地），および現地 調査により明らかにすることである.

石炭灰造粒物の覆砂材としての生物親和性を比較・評 価するために，在来底質，自然石，砂およびセメント固 化体を対照基質として，その物理化学的特性，溶存態个 オンの溶出特性，基質への微生物（細菌）の付着，基質 への珪藻類の付着，および二枚貝の行動選好性に関する 実験，調査を実施した。これら室内外での実験および現 地調査により，従来評価されていなかった石炭灰造粒物 の材料配合による物理化学的特性の変化と生物親和性に 関する新たな知見が得られた。

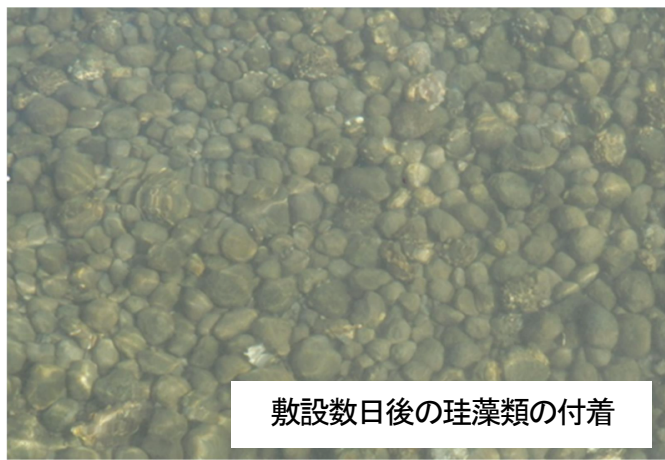

写真-1＼cjkstart海域への石炭灰造粒物の敷設状況 


\section{2. 石炭灰造粒物の物理化学特性}

\section{（1）石炭灰造粒物の底質改善に係る材料特性}

石炭灰造粒物は，火力発電所から発生するフライアッ シュをセメントと混合し，適量の加水により造粒・固化 した海砂代替材である. 中央粒径 $\mathrm{d}_{50}=20 \mathrm{~mm}$ 程度の礫状 材料であり，覆砂材として硫化水素の発生抑制・吸着お よびリン酸（栄養物質）の吸着効果が確認されている. 覆砂材, 干潟再生材として酸化物を溶出する空隙率の大 きい石炭灰造粒物透水層を設置することにより，堆積泥 による目詰まり防止（イオン交換による透水性の向上， 間隙内一の大気の取り込みと流れによる DO 供給（酸化 状態の確保), そして有機泥の分解と流出による有機泥の 減量が期待される 2),3).

\section{(2) 配合調整した石炭灰造粒物の物理化学特性試験}

石炭灰 (FA) と高炬セメントの添加率を変化させて覆 砂材（粒径 $10 \mathrm{~mm}$ ）を試験製作（表-1）した．なお，比 較試料としてFA添加率を可能な限り大きくしたFA固化 体（ケース 1)，およびFAを添加しないセメント固化体 （ケース 5）を試作した。覆砂材としての特性に影響を 与えると想定される空隙率，比表面積，細孔径分布，お よび反応性を評価する非晶質強度を定量的に評価した。

比表面積は，気体吸着法（窒素吸着，BET 多点法）に より測定した. また空隙率, 細孔径分布は水銀圧入法 (測 定範囲 : 0.005 $120 \mu \mathrm{m}$ ）により測定した. なお，空隙率 は単位質量あたりの全細孔容積に，乾燥密度を積算した 值である．空隙の分布は細孔径に対する細孔容積と加積 細孔容積率として表示した。併せて，XRD（X 線回折） により結晶組成物（化合物）を同定し，同定された物質 の半定量解析（Reference Intensity Ratio 法）を実施した. 非晶質量の評価は，結晶質と非晶質のピークを分離して 非晶質強度を全強度（非晶質含）で除すことで定性的に 算出した.

\section{（3）物理化学特性試験の結果と考察}

覆砂材を還元有機泥層に敷設する場合，有機泥表層の 含水比は高く, 泥層支持力は不足する. 有機泥層へのめ り込み量低減のため覆砂材は軽量であることが望ましい.

FA 添加量に比例し乾燥密度は低下 (図-1) 寸る. これ はセメントに比較し FA の密度が小さいためである。一 方，空隙率はFA95\%（ケース 1）で大きいが，セメント 添加率が極端に低く, 覆砂材に要求される材料強度は満 足されない，要求強度を満足する FA 添加率はケース 2 以下であり，FA70\%で空隙率が最大となっている. これ は比表面積（図-2）が FA70 \%で最も高くなっている結 果と一致する．細孔容積分布（図-3）と加積細孔容積分 布（図-4）も FA の添加率に応じて大きく性状が異なっ
表-1 試験製作した覆砂材（石炭灰造粒物）の配合

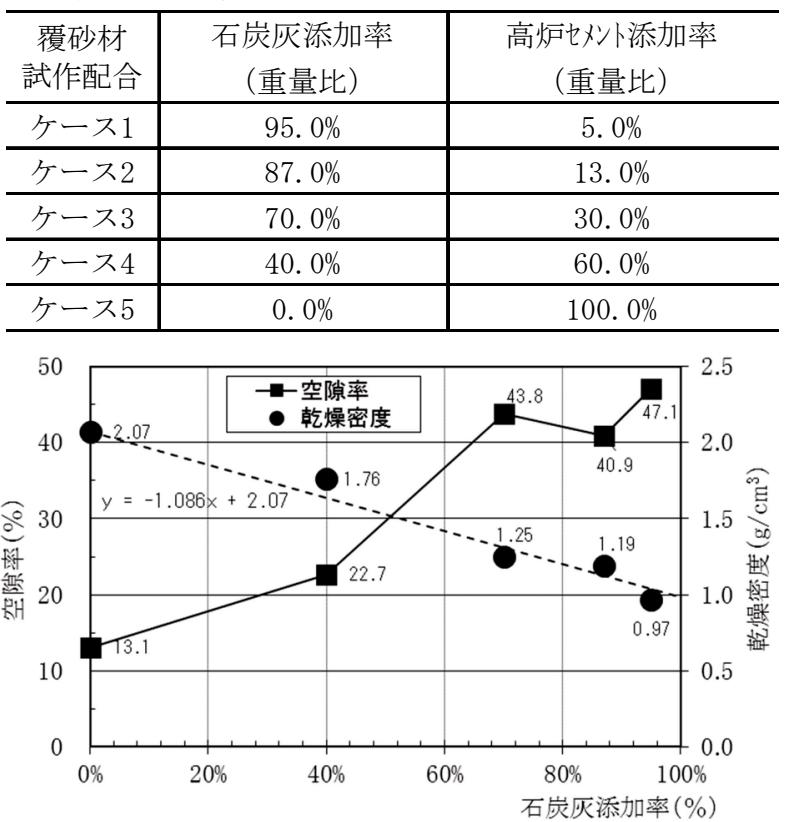

図-1＼cjkstart覆砂材の配合と空陌率・乾燥密度の関係

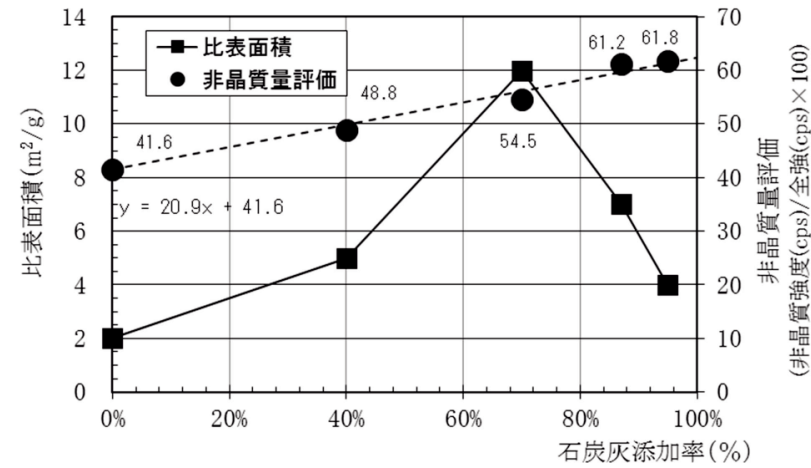

図-2 覆砂材の配合と比表面積・非晶質量評価の関係

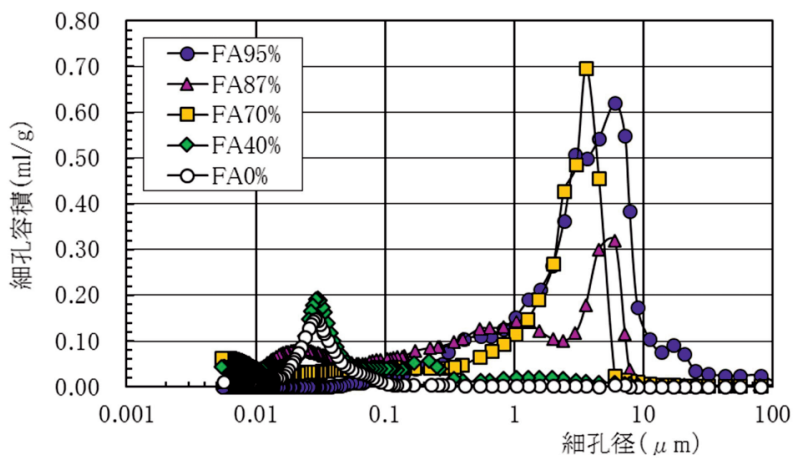

図-3 覆砂材の細孔容樍分布

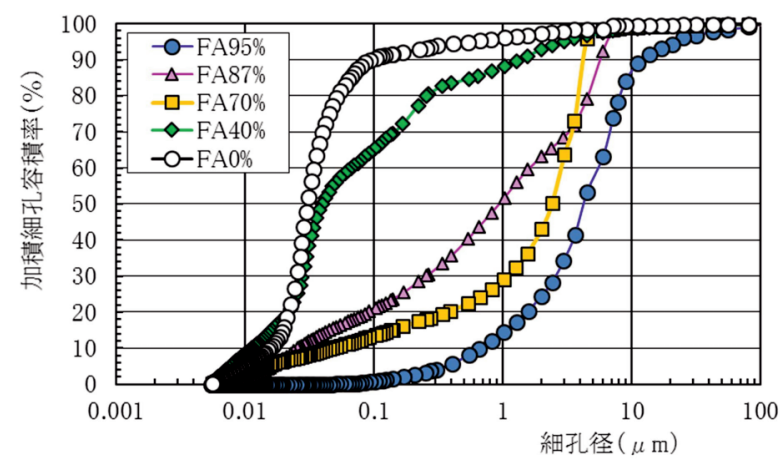

図-4 覆砂材の加積細孔容積率分布 
ている．覆砂材の空隙率，比表面積が大きいと底質中の 間隙水との接触面積が大きくなるため, 溶存態イオンの 溶出およびイオン交換等の化学反応性が向上すると評価 できる．また，非晶質量評価が高いほど，覆砂材の組成 物質は結晶化しておらず溶存態イオンの溶出が高いと考 察する. 本実験においては, FA 添加率が高いほど非晶質 量は高く, 結晶化が促進されていない結果が得られた.

一方で, 石炭灰造粒物の硬化は, セメントの水和反応, および水和物と FA とのポゾラン反応によるものであり, 両反応により比表面積と空隙率を最適化する添加率が存 在する. 比表面積および細孔容積分布から FA70 \% 程度 が覆砂材として反応性が高いと実験結果から評価できる。

\section{3. 覆砂材からの溶存態イオンの溶出特性}

\section{（1）溶存態イオンの溶出試験方法}

広島湾ではカキ養殖が盛んであり, カキの主要な餌で ある珪藻が成長段階に必要とするケイ酸イオンが海域お よび干潟覆砂材から供給されることを想定し溶出試験を 長期的（300 日間）に実施した. 併せて石炭灰造粒物の 主要な組成物質であるが溶出特性が明らかにされていな

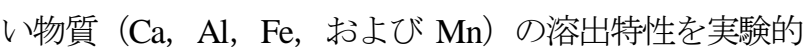
に評価した. 溶出試験は石炭灰造粒物（覆砂材：配合ケ 一ス 2)，広島県産自然石 (花崗岩)，および海域工事で 用いられる高炉セメント B 種コンクリート（呼び強度 : $30 \mathrm{~N} / \mathrm{mm}^{2}$ ) を比較材料として室内実験により実施した. 測定結果を確認しながら十分な溶出が確認されるも のについて，長期的（300 日間）に実験を継続した。試 験材料をイオン交換水で洗浄しプラスチック製ネットに 入れてアクリルパイプ内に吊るし，イオン交換水 $2 \mathrm{~L}$, 固液比 $2.5 \%, 20{ }^{\circ} \mathrm{C}$ の恒温槽内で, 直上水をスターラー で攪汼した。経過日数毎に，試料を採水し，乃過後（ろ 紙 No5 C)，各測定項目を分析（表-2）した。 なお，実験 開始 30 日までは，溶解度維持のため 10 日毎にイオン交 換水を全て入れ替えた. ケイ素の測定には，吸光光度計 (UV1600)，その他の測定物質には ICP 質量分析装置 （Agilent 7500 ce）を使用した. 測定結果は材料重量で除 して単位重量当りの溶出量により評価した.

\section{（2）溶出特性試験の結果と考察}

実験開始から 300 日間の測定対象物質の溶出特性を評 価するとともに，その結果から比較材料との相違を考察 する. 鉄, マンガンについては，90 日間測定を実施した が，どの材料からもほぼ全試料が定量下限值未満の測定 結果であったため, 90 日間で測定を中止した. 石炭灰造 粒物の主な組成物である Ca イオンの溶出量（図-5）が 多い結果であった，自然石である花崗岩からは，各溶存 態イオンの溶出は定量下限值以下で，有意な值は確認さ
れなかった，石炭灰造粒物とコンクリートからの300 日 間の溶存態イオン溶出量を比較すると Caイオン (図-5) については，ほぼ同等，Siイオン（図-6） は約 5 倍， $\mathrm{Al}$ イオン (図-7) は約 3 倍の溶出が確認された.

$\mathrm{Ca}$ イオンは, 石炭灰造粒物の組成物質から遊離, 溶出 したものと評価できる．コンクリートのセメント添加量 は $300 \mathrm{~kg} / \mathrm{m}^{3}$ 以上であり, 試験に用いた石炭灰造粒物の セメント量と比較し 2 倍程度であるにも関わらず Ca イ オンの溶出量は同程度であった。これは石炭灰造粒物の 空隙率，比表面積および非晶質量の特性に起因すると考 察する. Ca イオン, $\mathrm{Si}$ イオンは, 溶出速度が一定勾配で 維持されており，1 年程度は安定して溶出機能が維持さ れると評価できる．一方で， $\mathrm{Al}$ イオンは，180 日経過以 降はその溶出が止まっている.

表-2 溶存態イオンの測定方法

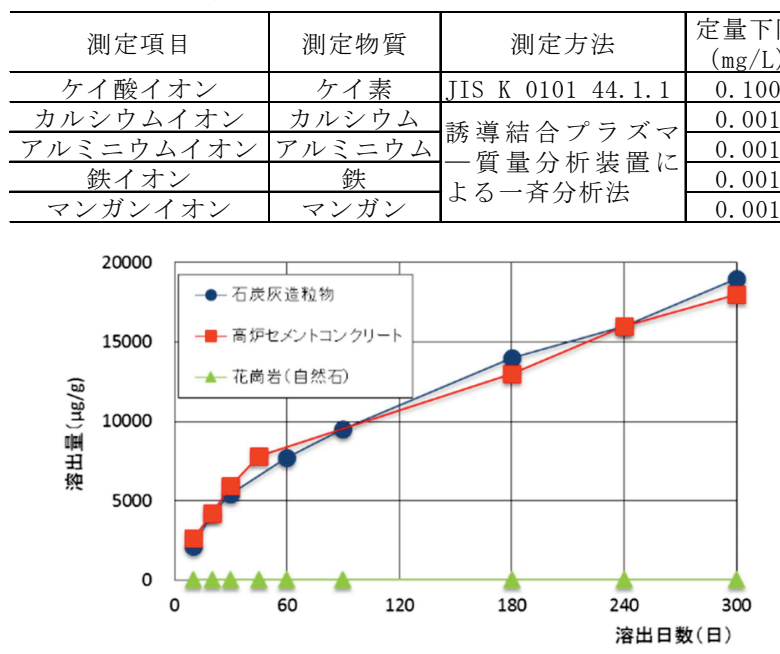

図-5 乾燥重量当りのカルシウムイオン溶出量

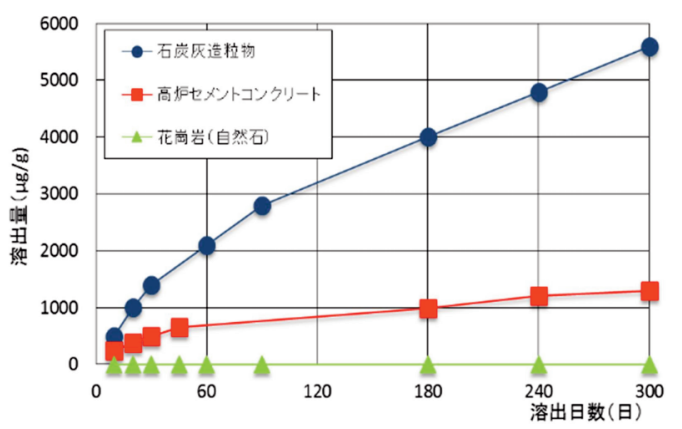

図-6＼cjkstart乾燥重量当りのケイ酸イオン溶出量

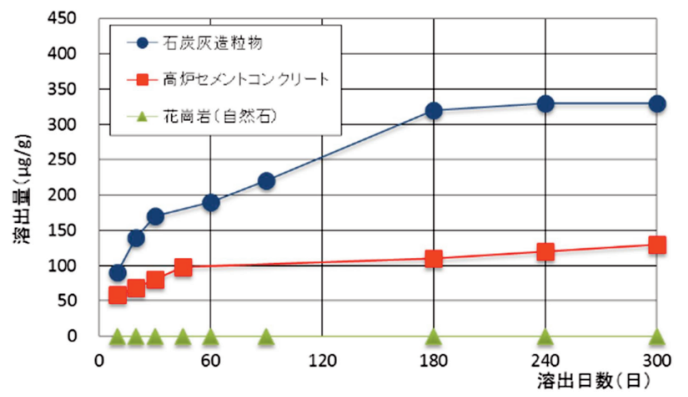

図-7 乾燥重量当りのアルミニウムイオン溶出量 


\section{4. 石炭灰造粒物への微生物の付着評価}

\section{（1） 微生物付着評価用試料の採取}

石炭灰造粒物の微生物 (細菌) 親和性を評価するため, 敷設した海域から石炭灰造粒物とその周辺底泥のサンプ ルを採取し，室内実験により細菌 DNA 分析を行った. それぞれのサンプルにより細菌担持の有無を分析し，石 炭灰造粒物の夕に担持されている細菌の同定を実施した。 採取箇所は表-3 に示寸干潟敷設箇所と湾域覆砂箇所 である. 干潟敷設箇所は， $4 \mathrm{~m}$ 程度の潮位変動により干 出する河岸干潟の有機泥上に敷設された石炭灰造粒物で, 好気環境の底質である。一方，湾域覆砂箇所は，湾内の カキの垂下式養殖場力キ筏下の底質に覆砂された石炭灰 造粒物で, その底質 DO は夏季に $3 \mathrm{mg} / \mathrm{L}$ 以下となること もあり嫌気環境の底質といえる，それぞれの底質に敷設 された造粒物と対照試料として周辺底泥を採取し，その 基質に付着する細菌を評価した.

\section{（2）基質に付着した微生物の細菌群集構造解析}

採取した試料から Ultra Clean DNA Isolation kit（MoBio 社製）を用いて細菌のDNA を抽出し，DNA を増幅させ 細菌群集構造解析により付着細菌を同定した。

好気環境および嫌気環境ともに，造粒物と対照底泥の 細菌 DNA 解析結果は類似し，それぞれの環境で同属の 細菌の付着が推定された。好気環境では造粒物試料にの み, 強い蛍光輝度のバンドが 2 箇所，嫌気環境において も造粒物試料にのみ, 強い蛍光輝度のバンドが 2 箇所確 認された。これらのバンドは, 造粒物一卓越して付着し ている細菌の存在を示しており, PCR-変性剤グラジエン トゲル電気泳動（DGGE）法により，それぞれの 2 本の バンドに該当する細菌を同定した。

\section{(3) 付着微生物の評価および考察}

好気環境，嫌気環境のそれぞれにおいて，同定した結 果を表-3に示す，好気環境の 2 本のバンドは，いずれも Sphingomonas 属であった. Sphingomonas 属は好気性細菌 で基質表層にバイオフィルムを形成し油類を分解するこ とが知られている。また，嫌気環境の 2 本のバンドは, Acidovorax属, およびPropionibacterium属と推定された. これらも基質表層にバイオフィルムを形成し，油類を分 解することが知られている.

石炭灰造粒物の敷設環境により，卓越して担持される 微生物が異なっている事が確認された。 干潮時に好気的 環境となる干潟域では好機性菌が卓越し, 有機物分解に 寄与している。カキ箋下の嫌気的環境では, 有機物分解 に関与する嫌気性菌が周辺泥より卓越している.

石炭灰造粒物に付着していた細菌は対照基質（周辺底 泥）では存在比率が低い結果であった。これは，石炭灰
表-3 造粒物に卓越した付着微生物（細菌）

\begin{tabular}{|c|c|c|}
\hline 採取箇所 & 干潟敷設箇所（表層） & 湾域覆砂箇所（表層） \\
\hline 採取時期 & 2012年11月 & 2012年11月 \\
\hline 採取箇所 & $\begin{array}{c}\text { 広島県広島市 } \\
\text { 一級河川太田川水系 } \\
\text { 河岸干潟 (潮位差 } 4 \mathrm{~m}) \\
\end{array}$ & $\begin{array}{c}\text { 広島県江田島市 } \\
\text { カ養殖箋下の底質 } \\
\text { 水深 } 11 \mathrm{~m}-14 \mathrm{~m} \\
\end{array}$ \\
\hline 敷設環境 & 好気環境 & 嫌気環境 \\
\hline 採取方法 & 干出時に採取 & 潜水作業により採取 \\
\hline $\begin{array}{c}\text { 石炭灰造粒物のみへ } \\
\text { 付着が確認された } \\
\text { 微生物 (細菌) }\end{array}$ & Sphingomonas 属 & $\begin{array}{c}\text { Acidovorax 属 } \\
\text { Propionibacterium 属 }\end{array}$ \\
\hline 微生物の特性 & $\begin{array}{l}\text { ·好気性菌 } \\
\text { • バイオフィルムより } \\
\text { 基質に付着 } \\
\text { ·有機物分解による浄化 } \\
\text { ·油分解菌 }\end{array}$ & 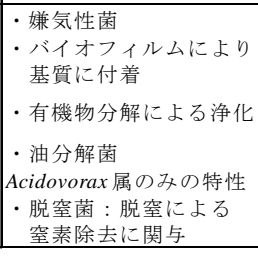 \\
\hline
\end{tabular}

造粒物の微生物（細菌）担持機能の高さを示していると 推定される. 石炭灰造粒物に卓越して付着していた細菌 は，いずれも油分解，有機物分解，および脱窒に関与す るものであった。これらは，石炭灰造粒物周辺での有機 物分解等に関係していると考察される.

卓越した細菌は，いずれもバイオフィルムを形成する 細菌であり，石炭灰造粒物の表面にバイオフィルムを形 成し付着していると考察される. 石炭灰造粒物の細孔径 は 0.01 5 $\mu \mathrm{m}$ の範囲（図-3）であり，細菌の大きさは数 $\mu \mathrm{m}$ であることから，細菌が担持されるには十分な空隙

（細孔）ではない，このことからも表層に生物膜を形成 して細菌が担持されていると評価できる.

本実験結果より，石炭灰造粒物は油分解能を有する細 菌を集積している可能性が高い．これは石炭灭造粒物の 微細孔に沈降泥由来の油分が吸着され，その油分を増殖 因子として，油分解菌が石炭灰造粒物周辺に生物膜を形 成していると想定される. 石炭灰造粒物敷設箇所ではnヘキサン抽出物の減少が複数箇所で報告 ${ }^{4), 5}$ されており, 本属の分解能によることが推察される.

\section{5. 覆砂材基質表層への珪藻類の付着}

\section{（1）石炭灰造粒物および周辺環境での藻類の付着調査}

干潟へ覆砂された造粒物には，従来から覆砂数日後に 藻類の付着が確認（写真-1）されている．一方で，還元 有機泥である在来底泥には, 目視で藻類の付着は確認さ れない. よって周辺の自然石に付着している藻類を併せ て採取，同定しその付着性を評価した.

採取箇所は，同じく広島市内一級河川太田川水系の河 岸干潟である。潮位差は約 $4 \mathrm{~m}$ あり, 干潟の干出時に試 料を採取した. 石炭灰造粒物敷設箇所で, $5 \mathrm{~cm} \times 5 \mathrm{~cm}$ の 面積を 5 回ケレンし, サンプル容器に採取した。同様に 周辺自然石からも試料を採取し実験室に持ち帰り同定を 行った。石炭灰造粒物敷設箇所の干潟底質の ORP は 224 
Eh.mV, 在来底泥箇所は, -229 Eh.mV であった. また, $\mathrm{pH}$ は，石炭灰造粒物箇所 7.93，在来底泥箇所は 7.02 で あり, 覆砂材敷設箇所は周辺より $\mathrm{pH}$ が高い值を示した。 これは石炭灰造粒物からの Ca イオン溶出（図-5）に起 因するものである.

\section{(2) 付着藻類の評価および考察}

干潟へ敷設した石炭灰造粒物表層と周辺自然石表層の 藻類を同定（図-8）した，優先種は，珪藻類（図-9）で あり，その細胞数と種類数を評価した．石炭灰造粒物の 表層には，従来から自然に存在する基質と同様の種が確 認された.このことから石炭灰造粒物に付着する藻類は, 従来からの優先種であり, 周辺自然石と比較し種類数は 同程度であるが, 細胞数は多く珪藻類が付着しやすい環 境にあると考察される. また，還元有機泥には，目視に よって付着は確認されず，石炭灰造粒物の敷設により従 来優先種である珪藻類が選好的に付着する環境を創造で きると想定される. これは自然石にはない溶存態イオン の溶出特性（図-6）によるものと考察する.

併せて，試料採取箇所の n-へキサン抽出物質を分析す ると石炭灰造粒物の付着泥は $300 \mathrm{mg} / \mathrm{kg}$, 周辺箇所表層 では $500 \mathrm{mg} / \mathrm{kg}$ であった. 同箇所でのセジメントトラッ プによる沈降泥の分析結果は $1,200 \mathrm{mg} / \mathrm{kg}$ であり, 石炭 灰造粒物による底泥油分の減少が確認された。この結果 についても選好的な付着微生物の関与が考察される.

\section{6. 二枚貝の行動選好性評価}

\section{（1）アサリの行動選好性評価実験方法}

広島市内を流れる一級河川本川（旧太田川）では，石 炭灰造粒物を用いて透水層を創出する干潟の底質改善事 業が行われている。これまでの調査により底質の改善, 多様な生物の生息環境の形成，石炭灰造粒物敷設前には 確認されなかった二枚貝のアサリが生息するようになっ たことが確認されている6).

干潟の有用底生生物である二枚貝（アサリ）を指標と して石炭灰造粒物の親和性を評価することとした. 本事 業箇所を実験サイトとして活用し，石炭灰造粒物層と砂 層でのアサリの行動選好性を実験した.アサリ行動選好 性実験の概要を図-10 に示す. 土畩間隙水の流動がある 箇所に $50 \mathrm{~cm} \times 50 \mathrm{~cm}$ の試験区を設定した. 試験区を金網 で区画し，アサリの試験区外への移動を抑止した．砂区 と石炭灰造粒物区，および上層，中層，下層へは自由に 移動可能である. なお，試験区は石炭灰造粒物敷設箇所 に設定しているため, 砂区の周囲は石炭灰造粒物の干潟 である．短期的な選好行動を評価するため，実験期間は 大潮から次の大潮までの 15 日間（2014.5.29〜2014.6.13） とした．石炭灰造粒物区の上層，中層，下層へそれぞれ

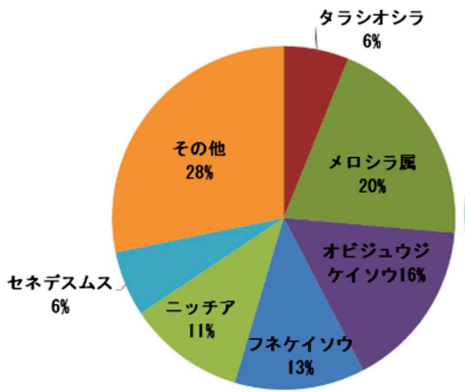

(a)石炭灰造粒物表層

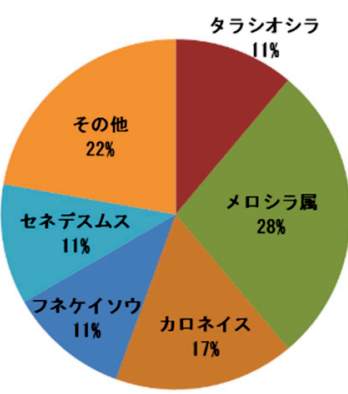

（b）周辺自然石表層
図-8 干潟で確認された藻類の同定結果
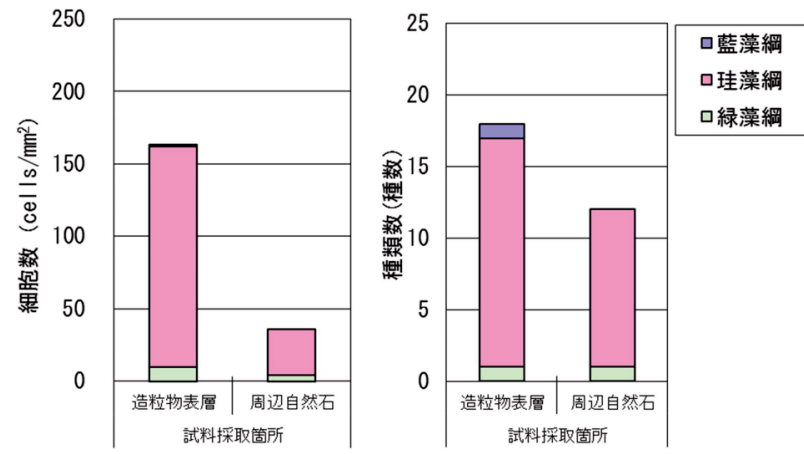

図-9 干潟で確認された藻類細胞数および種類数

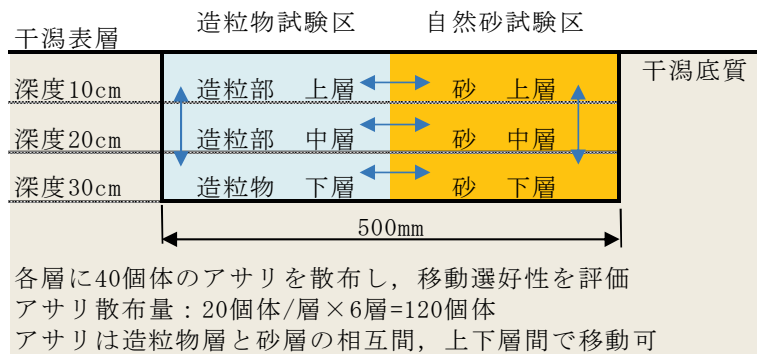

図-10 アサリ行動選好性実験概要
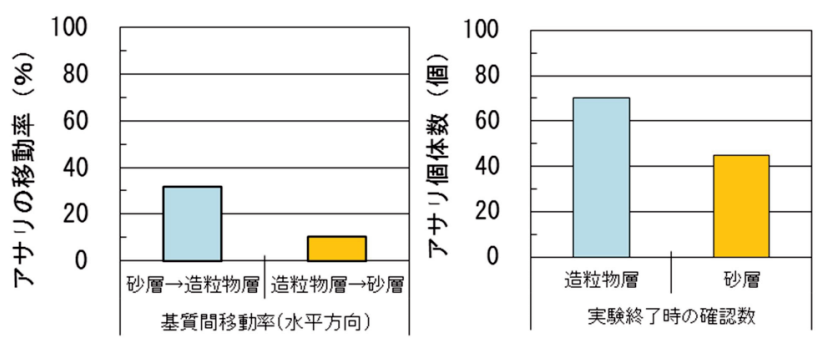

図-11 アサリ行動選好性実験結果

20 個体 (3 層 60 個体), また自然砂試験区の上層, 中層, 下層へそれぞれ 20 個体 (3 層 60 個体) のアサリ成貝（合 計 120 個体）を散布した．それぞれのアサリには，識別 可能なマーキングを施し，15 日後に移動箇所を確認した.

\section{（2）アサリの行動選好性実験結果および考察}

アサリの行動選好性実験結果を図-11 に示す．砂層か ら石炭灰造粒物層一 $30 \%$, 石炭灰造粒物層から砂層一 $10 \%$ 移動が確認された. 実験終了時には, 石炭灰造粒 
物層で 70 個体，砂層で 45 個体が確認された。 なお，下 層および中層に散布したアサリは総じて，上層へ移動す る傾向が確認された.

石炭灰造粒物は碩状材料であり，砂層（細粒分）を好 む事が想定されたが，現地実験では，アサリの砂層から 石炭灰造粒物層への選好行動が確認された．これは石炭 灰造粒物層の高い透水性に起因していると考察される. 中央粒径 $20 \mathrm{~mm}$ 程度ではあるが, 石炭灰造粒物と砂区相 互を移動することが確認された。これらの結果から透水 性が確保されれば，砂層と石炭灰造粒物層でのアサリの 選好行動に大きな相違はないと評価できる.

\section{7. おわりに}

本研究により明らかとなった主な結論を示す，室内外 での実験および現地調查により，石炭灰造粒物の材料配 合による物理化学的特性の変化と生物親和性に関する新 たな知見が得られた。

(1) 石炭灰造粒物は, セメント固化体と比較し, FA 添加 率を調整することで，空隙率，比表面積を調整可能であ り覆砂材としての効果を最適化する添加率が存在する. 実験結果の比表面積および細孔容積分布から FA70 \%程 度が覆砂材として反応性が高いと評価できる.

(2) 石炭灰造粒物の溶存態イオン溶出特性が定量的に把 握された. その主な溶出物質は, ケイ酸および Ca イオ ンであり，300 日後においても溶出特性は一定勾配を維 持している． $\mathrm{Al}$ イオンの溶出は，180 日程度であり， $\mathrm{Fe}$ イオン, Mnイオンの溶出は微小であった.

(3) 石炭灰造粒物表層に油分解菌がバイオフィルムを形 成し卓越して担持されることを確認した。これらは底泥 のn-ヘキサン抽出物の減少に寄与していると考察される. (4) 石炭灰造粒物一自然基質と同様に珪藻類が選好的に 付着されていることが明らかとなった. 還元有機泥表層 では目視で確認できる藻類は確認されず，還元有機泥上 に石炭灭造粒物を敷設することで，従来優先種であった 珪藻類による干潟の再生に寄与できる.

(5) 現地実験により, 石炭灰造粒物層内での二枚貝（ア サリ）の行動選好性が明らかとなった。礫状材料ではあ るが，アサリは造粒物層内で移動可能であり，砂層と同 様な行動選好性が確認された。

\section{参考文献}

1) 山地幹成: 海底清掃事業の底質改善効果，広島県立水 産海洋技術センター研究報告, 1, pp.22-27, 2006.

2) 中本健二, 廣中伸孝, 樋野和俊, 日比野忠史 : ヘドロ 堆積干潟での底質浄化能力を持つ作業場構築技術の 開発，土木学会論文集 B3 (海洋開発)，Vol.70, pp.1104-1109, 2014.

3）浅岡聡，山本民次: 石炭灰造粒物による硫化物イオン の除去，水環境学会誌，Vol.32，pp.363-368，2009.

4) 日比野忠史, 藤原哲宏, 田多一史, 中川保夫 : 廃棄物 リサイクル品を用いた底質改善手法の検討, 土木学会 論文集 B3（海洋開発），Vo1.67，pp.505-510，2011。

5) 井上省吾, 西野博史, 木村道夫, 日比野忠史, 首藤啓 : 石炭灰造粒物の海底被覆による海域環境の改善効果, 土木学会論文集 B3 (海洋開発), Vo1.67, pp.511-516, 2011.

6) 藤原哲宏, 中本健二, 日比野忠史, 斎藤直 ; 地下水が 遮断された河口干潟でのアサリ育成場の構築, 土木学 会論文集 B3（海洋開発）,Vol.69，pp.1024-1029，2013.

(2015.3.18 受付)

\section{Evaluation of biological affinity of granulated coal ash utilized to covering material in coastal sediments and tidal flats which sludge deposited}

\section{Kenji NAKAMOTO, Kazutoshi HINO, Takahito OIKAWA and Tadashi HIBINO}

Hiroshima coastal area is an enclosed bay in the western Seto Sea Inland. There are organic matter enriched coastal sediments and tidal flats due to the outfall of the domestic wastewater in the coastal area. Recently, sludge purification of organic matter enriched sediments using granulated coal ash (GCA) have been used in Hiroshima coastal areas. It has been proved that GCA can absorb the compounds of phosphorus, nitrogen and sulfer. However, the material properties of GCA for biological affinity have not been fully clarified. The purpose of this study is to evaluate of the biological affinity of GCA utilized to covering material. Laboratory experiments were carried out to evaluate the physical and chemical properties (e.g. surface area, pore ratio, and elation characteristics of ion) of GCA (covering material) and control materials (e.g. cement solidification, and natural stone) for biological affinity. And, field experiments were also carried out to estimate the adhesion of micro-organism, the exuberance of diatoms, and the behavioral preference of bivalve in GCA and control materials (e.g. conventional sediments, natural stone, sand). From our findings, it can be concluded that GCA can be used as a covering material to improve biological environment in organic matter enriched coastal sediments. 